\title{
MATHEMATICAL MODEL OF INDUCTION MOTOR WITH SERIES-CONNECTED STATOR AND ROTOR WINDINGS
}

\author{
T.A. Funk, kozinata@susu.ru, \\ Yu.S. Usynin, usyninys@susu.ru, \\ A.I. Grebnev, artgrebnev1219@gmail.com, \\ D.A. Ponosov \\ South Ural State University, Chelyabinsk, Russian Federation
}

\begin{abstract}
To provide for the cost-effective use of resources and energy conservation it is vital to enhance unregulated electric drives of copious working mechanisms. The technical process of these mechanisms requires relatively longstanding speed reduction under low static loads. Moreover, another relevant issue is choosing control systems of electric drives in the mentioned systems in accordance with the economic and maintenance aspects. The authors suggest using the systems of impulse-vector control system with wound rotor induction motor that have one essential drawback - the shaft encoder installation. The replacement of the shaft encoder with sensorless impulse-vector control system is complicated due to the lack of proper mathematical description of the electromagnetic processes in schemes with non-traditional windings stator and rotor connection. To solve this problem the authors have developed a mathematical description of impulse-vector control system with wound rotor induction motor supposed to be multiphase and asymmetrical. Angular dependencies of inductances, flux linkages, voltages of engine windings, circuit current and electromagnetic torque relatively to rotor location are derived. In addition to that, the mathematical modeling and research of induction motor configuration with a series connected windings fed by $\mathrm{AC}$ voltage source are presented. Equating rotor position in impulse-vector control system with wound rotor induction motor is considered possible through angular dependencies of drop voltages on stator and rotor windings.

Keywords: industrial mechanisms, electric drive, asynchronous motor, phase rotor, impulse-vector control system, sensorless control, mathematical model.
\end{abstract}

\section{Introduction}

There are diverse types of industrial mechanisms having technical process that requires relatively longstanding speed reduction with a decrease in static loads and restrained requirements for the accuracy of speed regulation. There are industrial fans, street conveyors in cold times, pumps of hydraulic presses, etc. $[1,2]$. A complete stop of the drive is unacceptable for these systems, while decreasing the speed to preserve energy and to use resources effectively is considered more appropriate.

In most cases, squirrel-cage induction motors and wound rotor induction motors are used as driving engines in the mentioned mechanisms. The motor speed remains unregulated or to the use of added resistances in circuits of rotor or stator is required for regulation. Having no regulation or deploying relay contact switching circuits causes high power consumption. High prices for energy and other recourses make it important to enhance the mentioned electric drives.

The implementation of two-unit frequency converter based on key elements is not appropriate for the mentioned mechanisms due to high price, complicated maintenance, and the high level of the operating staff's skills required [3, 4]. Impulse-vector control system for alternating current drives is used to create the current of the same frequency in the rotor and the stator, i.e. to exclude motor slip. Impulse-vector control is suitable for copious amounts of mechanisms because of its low price, low power consumption in low velocity mode and the absence of abundant control possibilities.
There are some scheme solutions featuring the impulse-vector control system with wound rotor induction motor [5]:

- impulse-vector control system with thyristor switches;

- impulse-vector control system with thyristor switches and damping circuit;

- impulse-vector control system with diodes and transistor;

- impulse-vector control system with damping circuit by symistors.

The control in these systems is performed depending on the angular location of a rotor, and, therefore, it is necessary to set a shaft encoder or to use sensorless control methods. Using shaft encoders for the mechanisms mentioned above is inappropriate, as it increases the cost and complicates the system. Furthermore, sensorless control methods have some advantages: the absence of the shaft encoder; simple installation, replacement, and operation; a possibility to use sensorless systems in cases when the measurement unit installation on the shaft is impossible (exposure to vibrations, radiation, high temperatures, etc.); a possibility of applying equipment for electric drives diagnostics; a possibility of decreasing of sustaining speed error, and augmenting the regulation range in contrast to open loop systems.

Using the known sensorless control methods $[6,7]$ or the development of unique algorithms of shaft position determination [8] for pulse-vector control system $[5,9]$ in most cases are complicated. It is due to the lack of appropriate mathematical description of electromagnetic processes in the schemes with 


\section{Электромеханические системы}

non-traditional windings connection of stator and rotor in the wound rotor induction motor.

Sensorless impulse-vector control system with wound rotor induction motor are multiphase, asymmetrical, nonlinear, impulse systems with series windings connection of stator and rotor, and, therefore, the development of mathematical description of such system is complicated and requires a complex stage-by-stage solution. So, the paper offers a description of electromagnetic processes in asymmetrical multiphase schemes with series windings connection of stator and rotor fed by AC voltage source for further implementation in sensorless impulse-vector control systems.

\section{Theoretical part}

Operating principles of impulse-vector control system with wound rotor induction motor

In impulse-vector control system with wound rotor induction motor $[5,9]$ the electromagnetic torque is created with the series connection of two stator phases through valve elements consequently to the two windings of the rotor. The magneto motive force (MMF) vector of stator windings moves in stator bore discretely with the step of 60 electrical degrees (el. degrees). Switching is effected depending on the shaft position, providing the orientation of $\mathrm{MMF}$ vectors of the stator and rotor windings respectively to the motive torque. One of the stator windings remains de-energized while two others are working. The third rotor winding is connected in parallel or remains de-energized during the operating cycle.

Consider the operation principles of the wound rotor induction motor with the series windings connection of the stator and rotor fed by harmonic voltage source. Assuming that the stator windings $A X$ and $B Y$ are fed by source voltage, the stator winding $C Z$ is de-energized at the considering (Fig. 1).

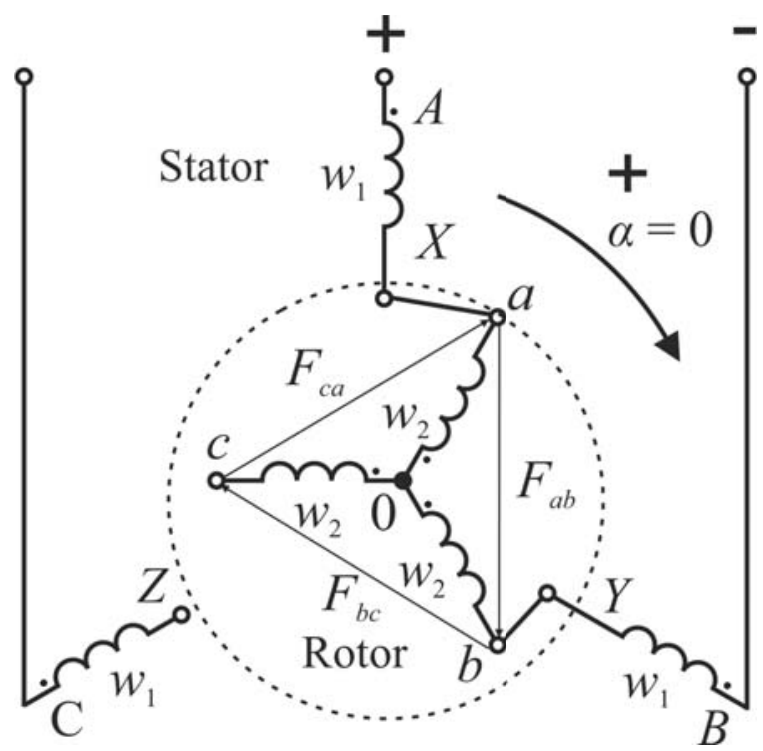

Fig. 1. Scheme of rotor and stator windings connection
Idealization of the machine

The magnetic field created by windings currents in alternating current machines is very non-uniform due to the complex configuration of the ferromagnetic cores boundaries, the peculiar layout of conductors with currents and the nonlinearities of the magnetic characteristic in the magnet core. Under such conditions, strict determination of the field is complicated, and, therefore, studying the electromagnetic processes in the researched machine and the compilation of differential equations employ a known idealization for the determination of magnetic field. It allows obtaining simple electromagnetic connections representing the main electromagnetic process in the machine. The idealization is based on the following principles: absence of the magnetic circuit saturation, hysteresis, losses in steel; absence of current displacement in copper windings; harmonious space distribution of MMF and magnetic induction curves; independence of reactive resistances of windings dispersion from the rotor location; complete symmetry of windings; uniformity of air gap [10,11].

Abstract designations and equivalent circuit

Consider: $i$ - instantaneous value of circuit current; $u, \psi-$ instantaneous values of voltage and winding flux linkage; $r$-active resistance of winding; $L$ - inductance of winding; $U, I$ - root-mean-square values of voltages and current. We use indexes to emphasize which winding is designated: phase stator windings $-A X, B Y, C Z$; phase rotor windings $-a 0, b 0$, $c 0$; equivalent rotor winding $-R$ (rotor winding is replaced with one equivalent winding according to [12]; voltages on rotor rings - $a b, b c, c a$. Double subscripts are applied to designate mutual inductances between the first and the second windings, e.g. mutual inductance of stator winding $A X$ and equivalent rotor winding $R$ is marked as $L_{A X R}$. In circuit $A B$ (Fig. 2)

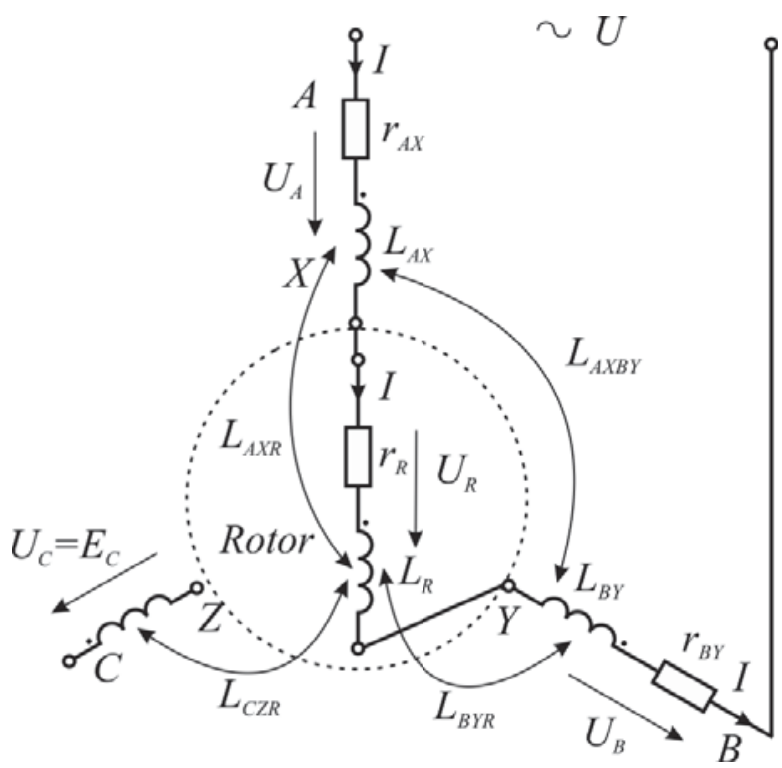

Fig. 2. Equivalent circuit $A B$ 
three coils are connected in series having active $r_{A X}, r_{B Y}, r_{R}$, own inductances $L_{A X}, L_{B Y}, L_{R}$ and mutual inductances $L_{A X B Y}, L_{A X R}, L_{B Y R}, L_{C Z R}$.

The equivalent winding of rotor turns by angle from 0 to 360 el. degrees. When flux linkage vector of equivalent rotor winding coincides with the flux linkage vector of the stator winding of phase $A$, it is considered as zero position. The stator winding $A X$ and the equivalent winding of the rotor have accordant connection, current flows into the beginnings of windings. The angle between flux linkage of the equivalent rotor winding and flux linkage of the stator winding $A X$ is equal to the value of the rotor $\alpha$ angular rate. The angle between flux linkage of stator winding $B Y$ and flux linkage of equivalent rotor winding is equal to $\alpha-120$ el. degrees. The winding stator $C Z$ is shifted by -240 el. degrees in relation to $A X$ winding.

\section{Flux linkages and windings inductances}

of the machine

The stator winding of phase $A$ is linked to magnetic fluxes created by both itself and other windings. A part of the magnetic flux created by the winding is linked only to its own coil of winding. This part is a leakage flux. The other part, apart from the turns of the own winding, covers the turns of the other windings, and, it is the main magnetic flux. The inductance of $L_{\sigma}$ connecting leakage flux of winding with the current flowing inside is leakage inductance. The inductance of $L_{M}$ defining flux linkage with the main flux is mutual inductance, or inductance of the main magnetic flux. Using these valuesallows presenting flux linkage of the phase $A$ in the scheme with equivalent winding of rotor and de-energized stator winding of $C Z$ in the following way:

$$
\psi_{A X}=L_{1 \sigma} \cdot i+L_{M} \cdot i+L_{A X B Y} \cdot i+L_{A X R} \cdot i
$$

Where $L_{A X B Y}$ - mutual inductance of the stator windings; $L_{A X R}-$ mutual inductance of the stator winding $A X$ and equivalent rotor winding $R ; L_{1 \sigma}$ - leakage inductance of the stator winding.

As stator windings have identical features, the magnetic flux created by the second winding current linking to the turns of the first winding is identical to the magnetic flux created by the first winding current linking to the turns of the second winding based on the assumed windings axes similarity and currents values equality. It is obvious that the pattern of the magnetic field will be similar and will not dependent on which winding current flows in under these conditions. Consequently, the inductance of the main magnetic flux will be equal to the stator windings mutual inductance in case the windings axes are the same.

The shift of the windings axes in space will cause the alteration of its mutual inductance proportional to the angle cosine of the shift. For the considered scheme, mutual inductance between stator windings $L_{A X B Y}$ is always positive. It is true due to two facts: these windings spaced at the angle of -120 el. degrees and current flows into the beginning of one winding outflowing from the beginning of another: $L_{A X B Y}=$ $=L_{0} \cos (-120+180)=0,5 L_{M}$, where $L_{0}=L_{M}-$ mutual inductance in case the windings axes are the same.

Current $i$ flows in the equivalent rotor winding $R$. As a result, the magnetic flux created by equivalent rotor winding is linked to the stator windings leading to the emergence of an additional constituent in the equation of stator winding flux linkage $L_{A X R} \cdot i$. As a rule, the amount of rotor winding turns $w_{2}$ for the typical induction motors is not equal to the number of the stator windings turns $w_{1}$. Consequently, the current flows in stator and rotor windings create different total magnetic fluxes. Assume $L_{A X R} \neq L_{M}$ to consider that fact. Then, mutual inductance of stator winding $A X$ and equivalent rotor winding is equal to:

$$
\begin{aligned}
& L_{A X R}=\sqrt{3} \cdot \frac{w_{2}}{w_{1}} \cdot L_{M} \cdot \cos (\alpha)= \\
& =\sqrt{3} \cdot \frac{E_{20}}{U_{1 N}} \cdot L_{M} \cdot \cos (\alpha),
\end{aligned}
$$

where $E_{20}$ - rotor rings voltage; $U_{1 N}$ - rated stator voltage.

Considering the mentioned dependencies of inductance, the equation of flux linkage for the phase $A$ may take the following form:

$$
\begin{aligned}
& \psi_{A X}=L_{1 \sigma} \cdot i+L_{M} \cdot i+0,5 \cdot L_{M} \cdot i+ \\
& +\sqrt{3} \cdot \frac{E_{20}}{U_{1 N}} \cdot L_{M} \cdot \cos (\alpha) \cdot i .
\end{aligned}
$$

Stator windings $B Y$ and $A X$ have the same properties. Therefore, considering the location of stator winding $B Y$ relating to $A X$ it is possible to represent mutual inductance between $B Y$ and equivalent rotor winding as follows:

$$
\begin{aligned}
& L_{B Y R}=\sqrt{3} \cdot \frac{w_{2}}{w_{1}} \cdot L_{M} \cdot \cos (\alpha+60)= \\
& =\sqrt{3} \cdot \frac{E_{20}}{U_{1 N}} \cdot L_{M} \cdot \cos (\alpha+60),
\end{aligned}
$$

The equation of flux linkage for winding of phase $B$ :

$$
\begin{aligned}
& \psi_{B Y}=L_{1 \sigma} \cdot i+L_{M} \cdot i+0,5 \cdot L_{M} \cdot i+ \\
& +\sqrt{3} \cdot \frac{E_{20}}{U_{1 N}} \cdot L_{M} \cdot \cos (\alpha+60) \cdot i .
\end{aligned}
$$

Stator winding $C Z$ is de-energized (Fig. 2), and, therefore, it produces no leakage flux and part of the main magnetic flux. The magnetic fluxes created by windings $A X$ and $B Y$ and linked to $C Z$, are equal in value and oppositely directed. Hence, the flux linkage of de-energized winding $C Z$ is equal to the flux linkage created by the equivalent rotor winding relying on the relative position:

$$
\begin{aligned}
& \psi_{C Z}=L_{1 \sigma} \cdot 0+L_{M} \cdot 0+0,5 \cdot L_{M} \cdot i-0,5 \cdot L_{M} \cdot i+ \\
& +\sqrt{3} \cdot \frac{E_{20}}{U_{1 N}} \cdot L_{M} \cdot \cos (\alpha-60) \cdot i= \\
& =\sqrt{3} \cdot \frac{E_{20}}{U_{1 N}} \cdot L_{M} \cdot \cos (\alpha-60) \cdot i
\end{aligned}
$$




\section{Электромеханические системы}

Mutual inductance between equivalent rotor winding and stator windings $A X$ and $B Y$ :

$L_{A X R}=L_{M} \cdot \cos (\alpha) \cdot i, \quad L_{B Y R}=L_{M} \cdot \cos (\alpha+60) \cdot i$.

Flux linkage value of equivalent rotor winding is equal to:

$\psi_{R}=\sqrt{3} \cdot L_{2 \sigma} \cdot i+\sqrt{3} \cdot \frac{E_{20}}{U_{1 N}} \cdot L_{M} \cdot i+L_{M} \cdot \cos (\alpha) \cdot i+L_{M} \cdot \cos (\alpha+60) \cdot i$.

To evaluate the rotor windings flux linkages $a 0, b 0, c 0$ it is crucial to consider the scheme with three-phase rotor winding (Fig. 1). Symmetric three-phase rotor winding is wye-connected; windings are shifted by 120 el. degrees in relation to each other. Windings $a 0$ and $b 0$ are connected with stator windings in series, winding $c 0$ is de-energized.

The leakage inductance of rotor winding is $L_{1 \sigma}$. Making the same assumptions as those mentioned above for the flux linkages of rotor winding and considering the interaction of stator windings $A X$ and $B Y$ separately, we obtain the following equations:

$$
\begin{aligned}
& \psi_{a 0}=L_{2 \sigma} \cdot i+\frac{E_{20}}{U_{1 N}} \cdot L_{M} \cdot i+L_{M} \cdot[\cos (\alpha+30)+\cos (\alpha+150)] \cdot i ; \\
& \psi_{b 0}=L_{2 \sigma} \cdot i+\frac{E_{20}}{U_{1 N}} \cdot L_{M} \cdot i+L_{M} \cdot[\cos (\alpha+330)+\cos (\alpha+30)] \cdot i ; \\
& \psi_{c 0}=L_{M} \cdot[\cos (\alpha+270)+\cos (\alpha+150)] \cdot i .
\end{aligned}
$$

Using the mentioned idealization to calculate the magnetic flux leakage inductances, own inductances illustrating the interaction of winding with its own magnetic flux and mutual inductances between stator windings does not dependent on the angle of rotor rotation.

Voltages, circuit current and torque of the studied machine

Instantaneous values of source voltages in three-phase network may be written as follows:

$$
\begin{aligned}
& u_{A}=U_{m} \cdot \sin (\omega t) ; \\
& u_{B}=U_{m} \cdot \sin (\omega t-120) ; \\
& u_{C}=U_{m} \cdot \sin (\omega t-240),
\end{aligned}
$$

where $u_{A}, u_{B}, u_{C}$ - instantaneous values of three-phase network; $U_{m}$ - amplitude of source voltage instantaneous value; $\omega=2 \pi f$ - circular frequency $(f$ - power frequency); $t$ - time.

Equations of instantaneous values representing the electrical condition of the system according to the second Kirchhoff law and Faraday law for the considered equivalent circuit may be written in the following way:

$$
u_{A}-u_{B}=2 \cdot i \cdot\left(r_{1}+r_{2}\right)+\frac{d \Psi_{A X}}{d t}+\frac{d \Psi_{B Y}}{d t}+\frac{d \Psi_{R}}{d t},
$$

where $r_{1}, r_{2}-$ active resistances of stator and rotor.

Applying the values of inductances and flux linkages to instantaneous values equations, we calculate the derivative value of the circuit current:

$$
\frac{d i}{d t}=\frac{u_{A}-u_{B}-2 \cdot i \cdot\left(r_{1}+r_{2}\right)+2 \cdot L_{M} \cdot i \cdot n \cdot[\sin (\alpha)+\sin (\alpha+60)]}{2 L_{1 \sigma}+2 L_{2 \sigma}+2 \cdot L_{A X B Y}+\left(2+\sqrt{3} \cdot \frac{E_{20}}{U_{1 N}}\right) \cdot L_{M}+1,8 \cdot L_{M} \cdot \cos (\alpha)+1,8 \cdot L_{M} \cdot \cos (\alpha+60)},
$$

where $n=d \alpha / d t$ - rotor speed. For locked rotor $n=0$.

According to the second Kirchhoff law and Faraday's law for the considered equivalent circuit (Fig. 2) equations for the instantaneous values of voltages on stator windings and rotor rings take the following form:

$$
\begin{aligned}
& u_{A X}=r_{1} \cdot i+\frac{d \psi_{A X}}{d t}, u_{B Y}=r_{1} \cdot i+\frac{d \psi_{B Y}}{d t}, u_{C Z}=\frac{d \psi_{C Z}}{d t} ; \\
& u_{a b}=\sqrt{3} \cdot r_{2} \cdot i+\frac{d \psi_{a 0}}{d t}+\frac{d \psi_{b 0}}{d t} ; \\
& u_{b c}=\frac{\sqrt{3}}{2} \cdot\left(r_{2} \cdot i+\frac{d \psi_{b 0}}{d t}+\frac{d \psi_{c 0}}{d t}\right) ; \\
& u_{c a}=\frac{\sqrt{3}}{2} \cdot\left(r_{2} \cdot i+\frac{d \psi_{a 0}}{d t}+\frac{d \psi_{c 0}}{d t}\right) .
\end{aligned}
$$

The voltage drop on the engine windings are equal to the sum of self-induced EMF and mutual inductance EMF. Self-induced EMF of stator windings and equivalent rotor winding depends on the rotor angle. There is no current in a free stator winding $C Z$. Moreover, $C Z$ induces only self-induced EMF from the equivalent rotor winding $\left(U_{C}=E_{C}\right)$. 
The EMF inductance value may be split into two components. The first component $d \psi / d t$ is related to flux linkage variation in time due to currents variations in time is called transformation EMF similarly to the processes of motor field in the machine. The second component is $\omega \psi$, which comes from flux linkage variation in time due to the rotor rotation, and it is called rotational EMF.

It is appropriate to calculate the electromagnetic torque of the engine via the instantaneous values of induction motor internal coordinates. Furthermore, we use the equation of electromagnetic torque coming from the common assumption that the electromagnetic torque of the electric machine is equal to partial differential coefficient in geometric angle $\alpha$ from the total value of the electromagnetic energy:

$$
T=\frac{d W}{d \alpha}=\frac{d}{d \alpha}\left(\sum L_{j} \cdot i_{j}^{2}+\sum_{\substack{i=1 \\ j=1 \\ i \neq j}}^{3} L_{i j} \cdot i_{i} \cdot i_{j}\right),
$$

where $L_{j}$ - own winding inductance (in considered case $L_{A X}, L_{B Y}, L_{R}$ ); $i_{j}$ - current in the winding; $L_{i j}$ - mutual inductances $\left(L_{A X R}, L_{B Y R}, L_{A X B Y}\right)$. Consider: $d L_{j} / d \alpha=0$ and $d L_{A X B Y} / d \alpha=0$, therefore, no torque created by these values. In addition to that, the one current $i$ flows in the machine windings, electromagnetic torque is created only by two components, and then equation may be written as follows:

$$
T=2 \cdot \frac{d}{d \alpha}\left(L_{A X R} \cdot i^{2}+L_{B Y R} \cdot i^{2}\right)=2 \cdot i^{2} \cdot \frac{d L_{A X R}}{d \alpha}+2 \cdot i^{2} \cdot \frac{d L_{B Y R}}{d \alpha}=-2 \cdot L_{M} \cdot i^{2} \cdot[\sin (\alpha)+\sin (\alpha+60)]=T_{A X}+T_{B Y} .
$$

where $T_{A X}, T_{B Y}$-torques created by currents of stator windings $A X$ and $B Y$.

\section{Mathematical modeling}

It is implied that in case of rotor rotating by the value of $d \alpha$ current succeeds steady-state value, i.e. $d i / d \alpha=0$. It is true for low rotation speed. Computed dependencies of root-mean-square values of currents on the engine windings, circuit current and torque from angle of rotor rotation are obtained with the mentioned differential equations of instantaneous values using a model developed in MATLAB.

Instantaneous values of source voltage $u_{A}, u_{B}, u_{C}, u_{A}-u_{B}$ are shown in Fig. 3 a, instantaneous value of circuit current $i$ - Fig. $3 \mathrm{~b}$, instantaneous values of voltages on stator and rotor windings - Fig. $3 \mathrm{c}, \mathrm{d}\left(\alpha=0, U_{m}=117 \mathrm{~V}\right)$.

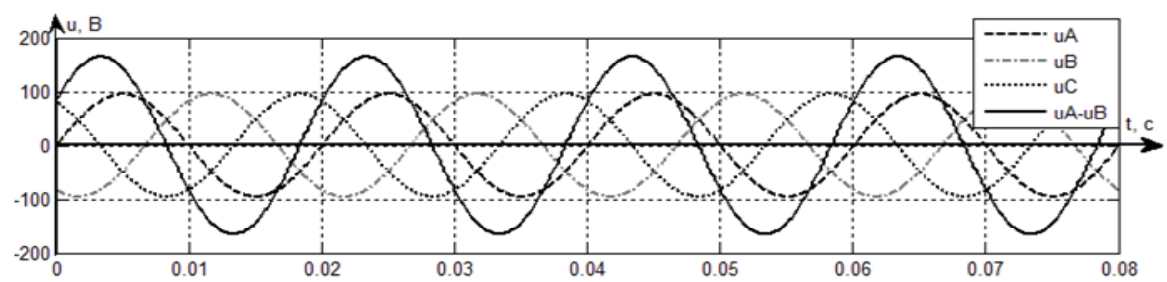

a)

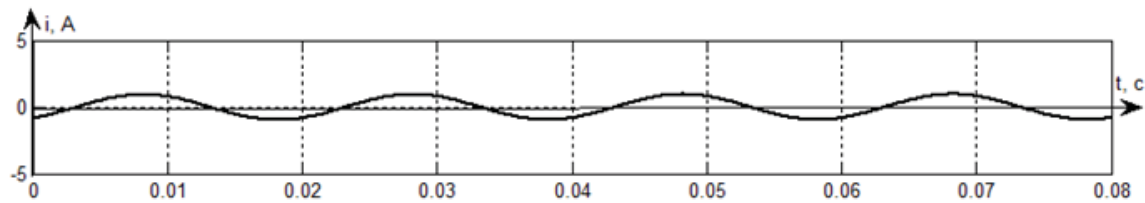

b)

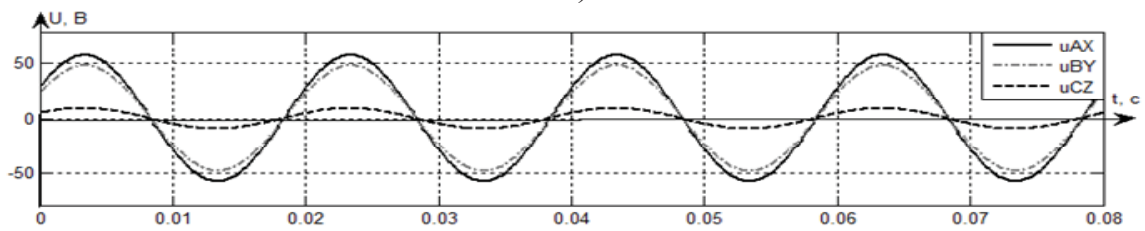

c)

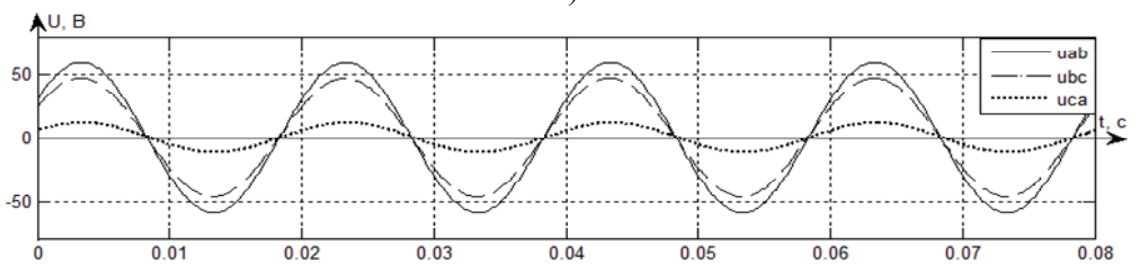

d)

Fig. 3. Instantaneous values of variables in the motor, $\alpha=0, U_{m}=117 \mathrm{~V}$ : source voltage (a), source current (b), voltages on stator windings (c), voltages on rotor rings (d) 


\section{Электромеханические системы}

Root-mean-square values of voltages on the engine windings, root-mean-square value of circuit current and electromagnetic torque variation $\alpha$ from $0^{\circ}$ to $360^{\circ}$ are illustrated in Fig. 4, 5.
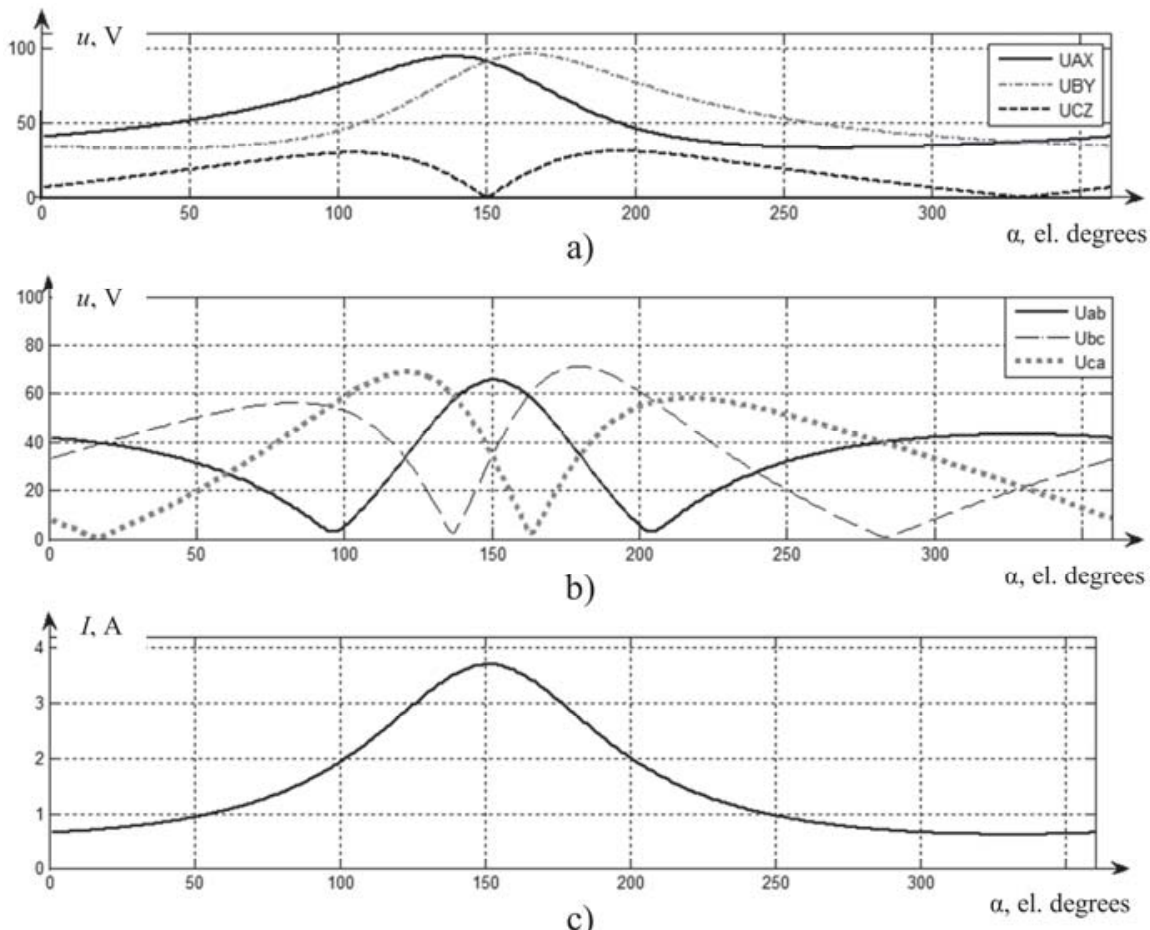

c)

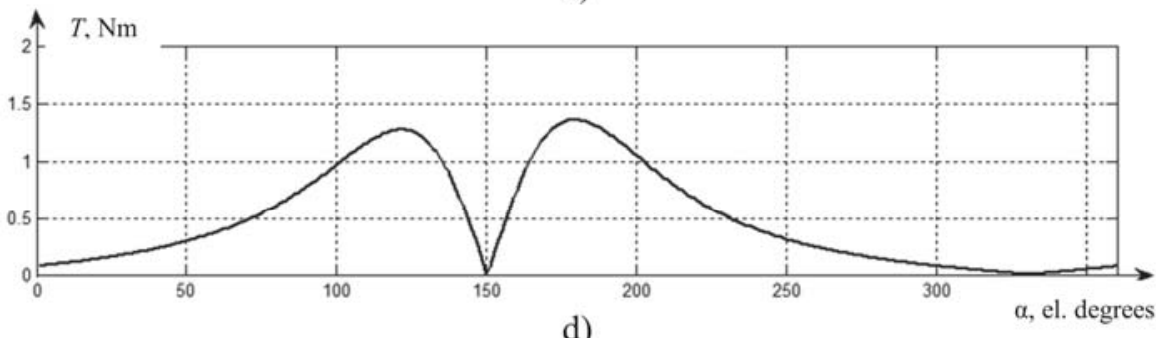

d)

Fig. 4. Root-mean-square values of variables in the motor ranging $\alpha$ from 0 to 360 el. degrees, $U_{m}=117 \mathrm{~V}$ : voltages on stator windings (a), voltages on rotor rings (b), circuit current (c), electromagnetic torque (d)

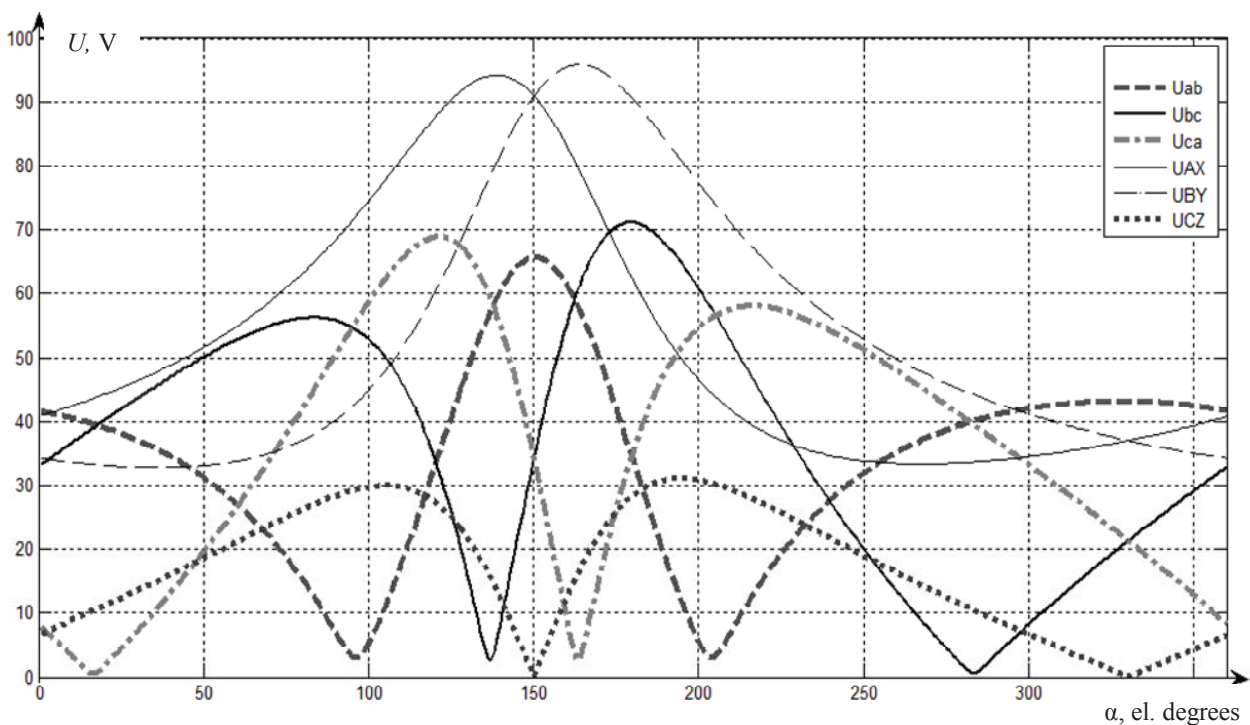

Fig. 5. Root-mean-square values of voltages on the engine windings ranging $\alpha$ from 0 to 360 el. degrees, $U_{m}=117 \mathrm{~V}$ 


\section{Experimental part}

Experiment description

Engine MTF 111-6 was used as an experimental wound-rotor induction motor with nameplate data illustrated in [13]. Two stator windings are connected in series fed by autotransformer (sinusoidal voltage with root-mean-square value of $117 \mathrm{~V}$, supply frequency value of $50 \mathrm{~Hz}$ ).

The rotor is mechanically turned clockwise with the step of 15 el. degrees ranging from 0 to 360 el. degrees and fixed in each position. Root-mean-square voltage valueson stator windings $U_{A X}, U_{B Y}, U_{C Z}$, voltage on rotor rings $U_{a b}, U_{b c}, U_{c a}$, circuit current $I$ and electromagnetic torque of the engine are determined for the fixed rotor.

\section{Experimental results}

The experimental data of root-mean-square values of voltages on the engine windings, circuit current and torque in their dependence on the angle of rotor rotation is shown in Fig. 6-8. Setting up the dependencies, torque leading to turning clockwise is positive. The experimental oscillograph traces of instantaneous values of current and voltages are similar to computed curves (Fig. 3).

Experimental dependencies of root-mean-square values of voltages on the engine windings $U_{A X}=f(\alpha)$, $U_{B Y}=f(\alpha), U_{C Z}=f(\alpha), U_{a b}=f(\alpha), U_{b c}=f(\alpha)$,
$U_{c a}=f(\alpha)$, circuit current $I=f(\alpha)$ and electromagnetic torque $T=f(\alpha)$ are similar to the calculated dependencies obtained based on the mathematical model. Therefore, the applied differential equations are a correct representation of the operation concepts of the scheme with seriallys connected rotor and stator windings fed by harmonic voltage source.

\section{Results analysis}

The dependencies of root-mean-square values of voltages on the engine windings, circuit current and electromagnetic torque on the angle of rotor rotation have certain features:

1. The graph of circuit current $I$ (Fig. 4c, 6) increases steadily ranging the angle from 0 to $150 \mathrm{el}$. degrees and declines ranging the angle from 150 to 360 el. degrees. The peak of the current is reckoned to be at 150 el. degrees, the negative peak - at 330 el. degrees. The type of the dependence complies with the equation of circuit current increment (14).

Turning the rotor relatively to the fixed stator impedance value changes, as mutual inductive reactance depends on the windings position. So, the circuit impedance value is the lowest at $150 \mathrm{el}$. degrees. The drop in voltage on the mutual inductance has a negative value:

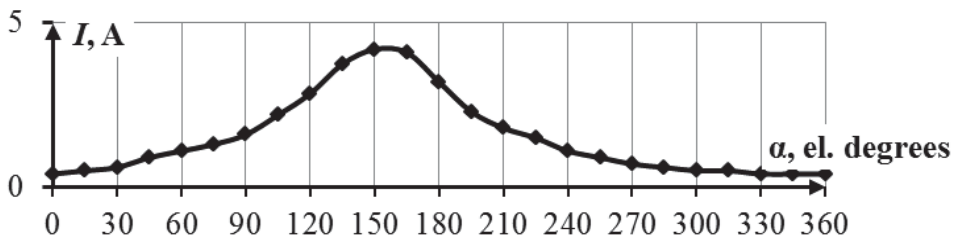

Fig. 6. Dependency of current on the angle of rotor rotation $I=f(\alpha)$

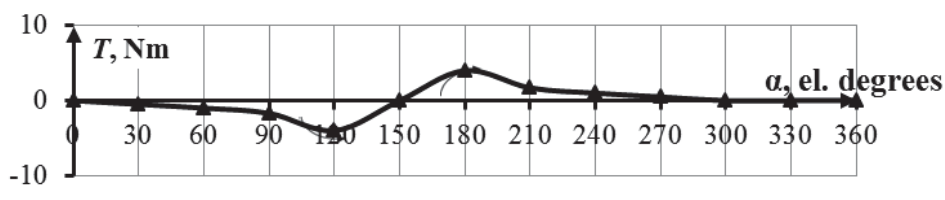

Fig. 7. Dependency of the engine electromagnetic torque on the angle of rotor rotation $T=f(\alpha)$

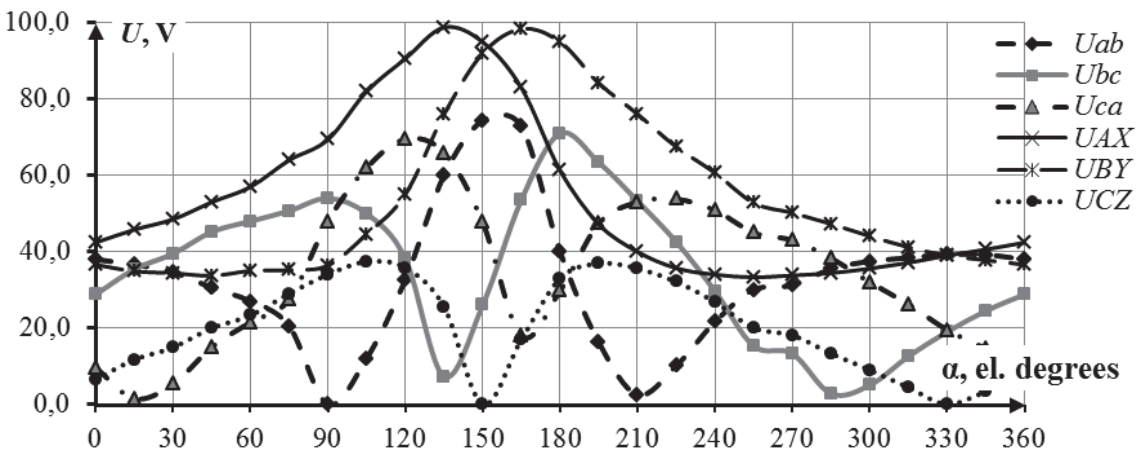

Fig. 8. Dependency of currents on stator winding and rotor rings on the angle rotor rotation:

$$
U_{A X}=f(\alpha), U_{B Y}=f(\alpha), U_{C Z}=f(\alpha), U_{a b}=f(\alpha), U_{b c}=f(\alpha), U_{c a}=f(\alpha)
$$




$$
\begin{aligned}
& u_{m}=\left(L_{m} \cos (\alpha)+L_{m} \cos (\alpha+60)\right) \cdot \frac{d i}{d t}= \\
& =\left(L_{m} \cos (150)+L_{m} \cos (210)\right) \cdot \frac{d i}{d t}=-1,73 L_{m} \cdot \frac{d i}{d t} .
\end{aligned}
$$

The circuit current value has a peak at the rootmean-square value of source voltage.

The circuit impedance value has the peak at $\alpha=330$ el. degrees. The drop in voltage on the mutual inductance has a positive value:

$$
\begin{aligned}
& u_{m}=\left(L_{m} \cos (\alpha)+L_{m} \cos (\alpha+60)\right) \cdot \frac{d i}{d t}= \\
& =\left(L_{m} \cos (330)+L_{m} \cos (390)\right) \cdot \frac{d i}{d t}=1,73 L_{m} \cdot \frac{d i}{d t} .
\end{aligned}
$$

The circuit current value is the lowest at the rootmean-square value of source voltage.

2. The voltage on the de-energized winging $U_{C Z}$ is equal to - $\left(U_{B Y}+U_{A X}\right)$ representing gap field strength depending on the torque. It is zero at $\alpha=150$ and $\alpha=330 \mathrm{el}$. degrees. In these positions the equivalent rotor winding is located orthogonally to the deenergized stator winding $C Z$ and does not induce EMF (Fig. 9).

The first position at $\alpha=150$ el. degrees is a position of instable equilibrium: having minimal alteration of angle the rotor turns clockwise or anticlockwise under the influence of the highest value of torque (Fig. 7). The vectors of stator MMF $F_{S}$ and rotor MMF $F_{R}$ are coincided (Fig. 9a). The second position $(\alpha=330$ el. degrees) is a position of stable equilibrium, changing angle in the range from 300 to 360 el. degrees the rotor is fixed or returned to position at $\alpha=330$ el. degrees, i.e. the position where the electromagnetic torque value is equal to zero (Fig. 7). The vectors of sta- tor MMF $F_{S}$ and rotor MMF $F_{R}$ coincide (Fig. 9b). The type of the electromagnetic torque dependence complies with equation (17).

3. At the positions where the voltage on the deenergized winding is equal to zero, the voltages on the stator windings switched "forward" and "backward" are equal. If the voltage on working "backward" winding is bigger than the voltage on working "forward" winding (in the range from 150 to $360 \mathrm{el}$. degrees not including) the engine leads to rotation clockwise. In addition to that, if the voltage on working "forward" winding is bigger than the voltage on working "backward" winding (in the range from 0 to 150 el. degrees) the engine leads to anticlockwise rotation.

4. Experimental dependencies $U_{a b}, U_{b c}, U_{c a}$ on the angle of rotor rotation shown in Fig. 8 comply with the equations 14 . The voltage value on the rotor rings goes through zero at $\alpha=90$ and $\alpha=210 \mathrm{el}$. degrees, the peak is at $\alpha=150$ el. degrees, as according to Kirchhoff law $U_{a b}=U-U_{A X}+U_{B Y}$ and for the considered angles $U-U_{A X}+U_{B Y}=0$. The voltage on the rotor rings $U_{a b}$ is equal to $-\left(U_{b c}+U_{c a}\right)$ due to $c 0$ is de-energized. The voltage on the rotor rings $U_{b c}$ can be determined as $U_{b c}=1,5 \cdot U_{C Z}-0,5 \cdot U_{a b}$, voltage $U_{c a}=-1,5 \cdot U_{C Z}-0,5 \cdot U_{a b}$.

\section{Conclusion}

1. The interaction analysis of the rotor and stator windings changing angular position of the rotor allowed finding out that the impulse-vector control system with wound rotor induction motor has unambiguous dependencies from the angular position of the rotor. The obtained angular dependencies vividly explain the physics of the stator and rotor windings interaction when the windings connected in series.

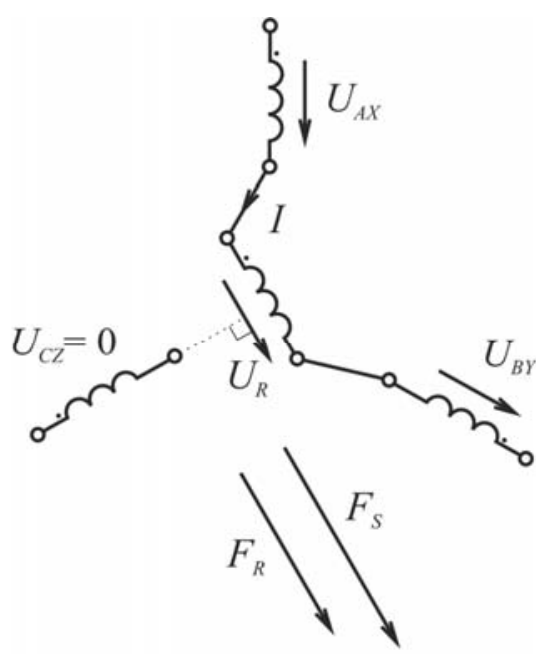

b)

Fig. 9. Mutual location of stator winding, equivalent winding and vectors of MMF of stator $F_{S}$ and rotor $F_{R} ; \alpha=150$ el. degrees (a) and $\alpha=330$ el. degrees (b) 
2. The obtained dependencies of the windings voltages, current and electromagnetic torque in the scheme with stator and rotor windings connected in series and fed by harmonic voltage source allowed the conclusion that the voltages values on the engine values may be used as input variables of angular rotor position estimator.

The work was supported by Act 211 Government of the Russian Federation, contract № 02.A03.21.0011.

\section{References}

1. Leznov B.S. Energosberezhenie i reguliruemyy privod v nasosnykh $i$ vozdukhoduvnykh ustanovkakh [Energy Saving and the Controlled Drive in Pumping and Blowing Installations]. Moscow, Energopromizdat Publ., 2006. 359 p.

2. Sarvarov A.S. Energosberegayushchiy elektroprivod na osnoe NPCh-AD s programmnym formirovaniem napryazheniya [Energy Efficient Electric Drive Based on CD-AD with Program Voltage Generation Control]. Magnitogorsk, MSTU Publ., 2001. 206 p.

3. Barats E.I., Braslavskiy I.Ya. [Voltage Control Unit with an Alerting Structure for the Frequency Transformer V/f Control System]. Elektroprivody peremennogo toka: Trudy XII nauchno-tekhnicheskoy konf [DC Electric Drives: Papers of XII Research and Technology Conference], Ekaterinburg, USTU Publ., 2001, pp. 117-120. (in Russ.)

4. Vishnu Kalaiselvan Arun Shankara, Subramaniam Umashankara, Shanmugam Paramasivamb, Norbert Hanigovszkic. A Comprehensive Review on Energy Efficiency Enhancement Initiatives in Centrifugal Pumping System. Applied Energy, 2016, vol. 181, pp 495-513.

5. Mironov L.M. [Substantiation of the Cycloconverters Spheres of Usage]. Trudy III Mezhdunarodnoy (XIV Vserossiyskoy) konferentsii po avtomatizirovannomu elektroprivodu AEP 2001 [Papers of the III International (XIV Russian) Conference on Automated Electric DriveAED 2001], Nizhny Novgorod, Vektor-TiS, 2001 , p. 222. (in Russ.)

6. Valov A.V., Funk T.A., Zhuravlev A.M., Sidorenko N.Y. Circuits of a Pulse-Vector Controlling Alternate Current Motor Drive. Russian Electrical Engineering, 2014, vol. 85 (10), pp. 613-615. DOI: $10.3103 / \mathrm{S} 1068371214100150$

7. Funk T.A., Saprunova N.M., Belousov E.V., Zhuravlev A.M. Indirect Determination of the Displacement in an Electric Motor Drive. Russian Electrical Engineering, 2015, vol. 86 (12), pp. 716-718. DOI: $10.3103 / \mathrm{S} 106837121512007 \mathrm{X}$

8. Holtz J. Sensorless Control of Induction Motor Drives. Proceedings of the IEEE, 2002, vol. 90 (8), pp. 1359-1394. DOI: 10.1109/JPROC.2002.800726

9. Tabbache B., Rizoug N., Benbouzid M.E.H., Kheloui A. A Control Reconfiguration Strategy for Postsensor FTC in Induction Motor-based EVs. IEEE Transactions on Vehicular Technology, 2013, vol. 62 (3), pp. 965-971. DOI: 10.1109/TVT.2012.2232325

10. Pal A., Kumar R., Das S. Sensorless Speed Control of Induction Motor Driven Electric Vehicle Using Model Reference Adaptive Controller. Energy Procedia, 2015, vol. 90, pp. 540-551. DOI: 10.1016/j.egypro.2016.11.222

11. Dominic D.A., Chelliah T.R. Analysis of Field-Oriented Controlled Induction Motor Drives under Sensor Faults and an Overview of Sensorless Schemes. ISA Transactions, 2015, vol. 53 (5), pp. 1680-1694. DOI: 10.1016/j.isatra.2014.04.008

12. Traoré D., Leon De J., Glumineau A. Adaptive Interconnected Observer-Based Backstepping Control Design for Sensorless Induction Motor. Automatica, 2012, vol. 48 (4), pp. 682-687. DOI: 10.1016/j.automatica.2012.01.018

13. Usynin Yu.S., Smirnov Yu.S., Kozina T.A., Valov A.V. Pulse-vector Control with Indirect Determination of Rotor Angular Position. Russian Electrical Engineering, 2013, vol. 84 (10), pp. 566-571. DOI: 10.3103/S1068371213100106

14. Usynin Yu.S., Valov A.V., Kozina T.A. Asynchronous Electric Drive with Pulse-Vector Control. Russian Electrical Engineering, 2011, vol. 82 (3), pp. 134-137. DOI: 10.3103/S1068371211030102.

15. Vol'dek A.I. Elektricheskie mashiny [Electrical Motors]. Leningrad, Energiya Publ., 1974. 840 p.

16. Vazhnov A.I. Perekhodnye protsessy v mashinakh peremennogo toka [Transient Processes in Alternating Current Motors]. Leningrad, Energiya Publ., 1986. 256 p.

17. Andreev V.P., Sabinin Yu.A. Osnovy elektroprivoda [Fundamentals of Electric Drive], Moscow, Gosenergoizdat Publ., 1963. 772 p.

18. AlekseevYu.V., Bogoslovskiy A.P., Pevzner E.M. Kranovoe elektrooborudovanie: spravochnik [Crane Electrical Equipment: Reference Book]. Moscow, Energiya Publ., 1979. 240 p.

Received 2 February 2017 


\title{
МАТЕМАТИЧЕСКАЯ МОДЕЛЬ АСИНХРОННОГО ДВИГАТЕЛЯ С ПОСЛЕДОВАТЕЛЬНО СОЕДИНЕННЫМИ ОБМОТКАМИ СТАТОРА И РОТОРА
}

\author{
Т.А. Функ, Ю.С. Усынин, А.И. Гребнев, Д.А. Поносов \\ Южно-Уральский государственный университет, г. Челябинск
}

\begin{abstract}
С целью ресурсо- и энергосбережения необходимо модернизировать нерегулируемые электроприводы большого класса рабочих механизмов, у которых по условиям технологического процесса требуется относительно длительное снижение скорости при уменьшении статических нагрузок. Актуальным является вопрос выбора систем управления электроприводами рассматриваемых механизмов по экономическим и эксплуатационным критериям. Для регулирования скорости в них авторы предлагают использовать системы импульсно-векторного управления асинхронным двигателем с фазным ротором (СИВУ АД с ФР), но существенным недостатком данных систем является наличие датчика положения на валу двигателя, обусловленное принципом работы. Замена механического датчика на систему косвенного определения положения ротора в СИВУ затруднена в связи с отсутствием соответствующего математического описания электромагнитных процессов в схемах с нетрадиционным подключением обмоток статора и ротора. Для решения данной проблемы авторами разработана математическая модель СИВУ АД с ФР как многофазной, несимметричной системы. Выведены зависимости индуктивностей, потокосцеплений, напряжений обмоток двигателя, тока цепи и электромагнитного момента от углового положения ротора. Приведены результаты математического моделирования и экспериментального исследования схемы с последовательно соединенными обмотками статора и ротора асинхронного двигателя при питании от источника синусоидального напряжения. Определена принципиальная возможность вычисления положения ротора в СИВУ АД с ФР по угловым зависимостям падений напряжений на обмотках статора и ротора.

Ключевые слова: промышленные механизмы, электропривод, асинхронный двигатель, фазный ротор, система импульсно-векторного управления, косвенное определение положения, математическая модель.
\end{abstract}

Статья выполнена при поддержке Правительства РФ (Постановление № 211 от 16.03.2013 г.), соглашение № 02.A03.21.0011.

\section{Литература}

1. Лезнов, Б.С. Энергосбережение и регулируемый привод в насосных и воздуходувных установках / Б.С. Лезнов. - М.: Энергопромиздат, 2006. - 359 с.

2. Сарваров, А.С. Энергосберегающий электропривод на осное НПЧ-АД с программньм формированием напряжения / А.С. Сарваров. - Магнитогорск: МГТУ, 2001. - 206 с.

3. Бараи, Е.И. Регулятор напряжения с переменной структурой для системы скалярного управления преобразователем частоты / Е.И. Бараи, И.Я. Браславский // Электроприводы переменного тока: тр. XII науч.-техн. конф. - Екатеринбург: УГТУ, 2001. - С. 117-120.

4. A comprehensive review on energy efficiency enhancement initiatives in centrifugal pumping system / Vishnu Kalaiselvan Arun Shankara, Subramaniam Umashankara, Shanmugam Paramasivamb, Norbert Hanigovszkic // Applied Energy. - 2016. - No. 181. - P. 495-513.

5. Миронов, Л.М. Обоснование областей применения непосредственньх преобразователей частоть / Л.М. Миронов; под ред. С.В. Хватова // Труды III Международной (ХІV Всероссийской) конференции по автоматизированному электроприводу АЭП 2001 (Нижний Новгород, 12-14 сентября 2001). - Нижний Новгород: Вектор-ТиС, 2001. - C. 222.

6. Circuits of a pulse-vector controlling alternate current motor drive / A.V. Valov, T.A. Funk, A.M. Zhuravlev, N.Y. Sidorenko // Russian electrical engineering. - 2014. - No. 85 (10). - P. 613-615. DOI: 10.3103/S1068371214100150

7. Indirect determination of the displacement in an electric motor drive / T.A. Funk, N.M. Saprunova, E.V. Belousov, A.M. Zhuravlev // Russian electrical engineering. - 2015. - No. 86 (12). - P. 716-718. DOI: 10.3103/S106837121512007X

8. Holtz, J. Sensorless control of induction motor drives / J. Holtz // Proceedings of the IEEE. - 2002. No. 90 (8). - P. 1359-1394. DOI: 10.1109/JPROC.2002.800726 
9. A control reconfiguration strategy for post-sensor FTC in induction motor-based EVS / B. Tabbache, N. Rizoug, M.E.H. Benbouzid, A. Kheloui // IEEE Transactions on Vehicular Technology. - 2013. - No. 62 (3). P. 965-971. DOI: 10.1109/TVT.2012.2232325

10. Pal, A. Sensorless speed control of induction motor driven electric vehicle using model reference adaptive controller / A. Pal, R. Kumar, S. Das // Energy Procedia. - 2015. - No. 90. - P. 540-551. DOI: 10.1016/j.egypro.2016.11.222

11. Dominic, D.A. Analysis of field-oriented controlled induction motor drives under sensor faults and an overview of sensorless schemes / A. Dominic, T.R. Chelliah // ISA Transactions. - 2015. - No. 53 (5). - P. 16801694. DOI: 10.1016/j.isatra.2014.04.008

12. Traoré, D. Adaptive interconnected observer-based backstepping control design for sensorless induction motor / D. Traoré, De J. Leon, A. Glumineau // Automatica. - No. 48 (4). - 2012. - P. 682-687. DOI: 10.1016/j.automatica. 2012.01.018

13. Pulse-vector control with indirect determination of rotor angular position / Yu.S. Usynin, Yu.S. Smirnov, T.A. Kozina, A.V. Valov // Russian electrical engineering. - 2013. - No. 84 (10). - P. 566-571. DOI: 10.3103/S1068371213100106

14. Usynin, Yu.S. Asynchronous electric drive with pulse-vector control / Yu.S. Usynin, A.V. Valov, T.A. Kozina // Russian electrical engineering. - 2011. - Vol. 82 (3). - P. 134-137. DOI: 10.3103/S1068371211030102.

15. Вольдек, А.И. Электрические машины / А.И. Вольдек. - Л.: Энергия, 1974. - 840 c.

16. Важнов, А.И. Переходные проиессы в машинах переменного тока / А.И. Важнов. - Л.: Энергия. Ленингр. отд-ние, 1986. - 256 с

17. Андреев, В.П. Основы электропривода / В.П. Андреев, Ю.А. Сабинин. - М.: Госэнергоиздат, 1963. $772 \mathrm{c}$.

18. Алексеев, Ю.В. Крановое электрооборудование: справ. / Ю.В. Алексеев, А.П. Богословский, Е.М. Певзнер. - М.: Энергия, 1979. - 240 с.

Функ Татьяна Андреевна, канд. техн. наук, доцент, кафедра «Автоматизированный электропривод», Южно-Уральский государственный университет, г. Челябинск; kozinata@susu.ru.

Усынин Юрий Семенович, д-р техн. наук, профессор, кафедра «Автоматизированный электропривод», Южно-Уральский государственный университет, г. Челябинск; usyninys@susu.ru.

Гребнев Артем Игоревич, магистрант, кафедра «Автоматизированный электропривод», ЮжноУральский государственный университет, г. Челябинск; artgrebnev1219@gmail.com.

Поносов Дмитрий Алексеевич, бакалавр, кафедра «Автоматизированный электропривод», ЮжноУральский государственный университет, г. Челябинск.

Поступила в редакцию 2 февраля 2017 г.

\section{ОБРАЗЕЦ ЦИТИРОВАНИЯ}

Mathematical Model of Induction Motor with SeriesConnected Stator and Rotor Windings / T.A. Funk, Yu.S. Usynin, A.I. Grebnev, D.A. Ponosov // Вестник ЮУрГУ. Серия «Энергетика». - 2017. - Т. 17, № 1. C. 77-87. DOI: 10.14529/power170111

\section{FOR CITATION}

Funk T.A., Usynin Yu.S., Grebnev A.I., Ponosov D.A. Mathematical Model of Induction Motor with SeriesConnected Stator and Rotor Windings. Bulletin of the South Ural State University. Ser. Power Engineering, 2017, vol. 17, no. 1, pp. 77-87. DOI: 10.14529/power170111 